\section{Speaking ill of the Dead}

SIR - I was disappointed by John L. Casti's remarks about the rock band "The Grateful Dead" in his review of Tyler Volk's Metapatterns: Across Space, Time, and Mind (Nature 377, 24; 1995).

Jerry Garcia, the band's lead guitarist, was no lightweight entertainer. On the contrary, his career has been likened to that of jazz greats such as Louis Armstrong, Miles Davis and Charles Mingus. "The Grateful Dead" were not only engaged with the real issues of our time but practically married to a philosophy of change through a very simple musical model. The beauty inherent to their wizardry was often astounding to behold, physically and spiritually. In addition to the musical magic they created for the pleasure of millions, the members of the band were socially conscious. They participated in countless benefits to fight homelessness, rape, AIDS, environmental issues and blindness, and helped to promote the handicapped and education. They were genuinely interested in preventing and relieving suffering and promoting hope through compassionate action.

Among other projects, their participation and influence helped to provide support for: more than 30,000 cataract operations and the building a state-of-theart eye hospital in the Lumbini zone of Nepal; more than 200,000 surgical operations at Aravind Eye Hospital in Madurai, India; nutrition, health and education programmes at three refugee camps in Mexico; the creation of the Jaguar Project to accompany refugees returning to Guatemala; devastated Guatemalan villages by supplying animals, tools and seeds to help reduce their dependence on imported fertilizers; Mayan farmers for community development projects such as housing, water supplies, health care and cottage industries; grassroots organizations on Native American reservations to provide health clinics, protect the environment and safeguard traditional knowledge; a range of grants to help preserve Tibetan culture.

Their accomplishments will ensure that they are remembered far beyond the life of Jerry Garcia and the musical life of "The Grateful Dead".

Joshua R. Schultz

Molecular Genetics Laboratory, University of Ottawa Heart Institute, Ottawa Civic Hospital, 1053 Carling Avenue, Ottawa, Ontario, Canada K1Y $4 E Y$

\section{Correspondence}

Letters submitted for Correspondence should be typed, double-spaced, on one side of the paper only, or e-mailed to nature@nature.com

\section{Pain pathways}

SIR - You recently published two Letters ${ }^{1.2}$ reporting a new ATP receptor on neurons in the pain pathway. I should like to expand on the brief reference to the historical background given in the accompanying News and Views article ${ }^{3}$. The papers published in the 1950 s by Francis and the late Pamela Holton ${ }^{4.5}$ gave good evidence that the transmitter for antidromic vasodilatation is ATP.

It was then already well established (see, for example, Thomas Lewis's classic of $1927^{6}$ ) that this phenomenon, blood vessel dilatation in an area of skin when the sensory nerve to that area is stimulated, is the efferent side of the axon reflex, the dilatation of skin vessels resulting from activation of pain fibres in the skin and conducted to nearby blood vessels through branches of those fibres. So the connection between ATP and pain goes back more than 40 years and is not a new idea as implied in the News and Views article. It is also depressing that authoritative works of 1971 and 1984 stated that the transmitter for antidromic vasodilatation was unknown ${ }^{7,8}$.

The motive given by the Holtons for setting out to identify the peripheral transmitter of these pain fibres was that it would provide a suggestion for the identity of the peripheral transmitter used at the central end of the same neurons in the spinal cord or brain stem, on the basis of the proposal by Henry Dale" in 1935 that a nerve cell was likely to use the same transmitter at both its peripheral and its central terminations. This farsighted plan by the Holtons links their work even more closely with the discovery of appropriate receptors on nerve cell bodies in the pain pathway. It is satisfying that their surmise, well known at the time, has at long last been given further support; sadly, Pamela Holten died at an early age in 1977 and never knew how accurately she and her husband had foreshadowed this discovery.

\section{Andrew Huxley}

Trinity College,

Cambridge CB2 1TQ, UK

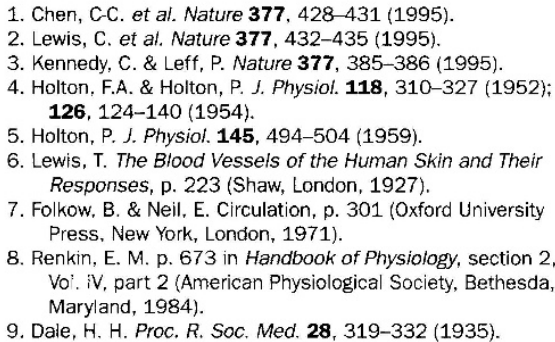

9. Dale, H. H. Proc. R. Soc. Med 28, 319-332 (1935).

\section{Security at MIT}

SIR - Your News story (Nature 378, 9; 1995) about a researcher's ingestion of phosphorus-32 at MIT, which quotes a statement by me, implies that I was aware of a security problem involving an open door in that laboratory. So far as I know, security practices there did not differ from practices in other laboratories at MIT where similar research was conducted. The incident to which I referred was in an entirely different MIT building. In addition, contrary to your article's wording, the door in question was only temporarily, not permanently, kept open, and keeping that door open was contrary to MIT policy, not to any requirement of law.

Kenneth D. Campbell

Massachusetts Institute of Technology, Cambridge,

Massachusetts 02139, USA

\section{Colonial dinosaur}

SIR - Kipling, had he been alive, would be glad to know that the fawning, loyal subject of colonial days looking up to his overlord for justice is not extinct. B. N. Dwivedi's letter (Nature 376, 545; 1995) shows the same sovereign contempt and distrust in which the colonial subject held his compatriots and the same eagerness to go crying and complaining about supposed wrongs to his master and cling to his garment.

Using the columns of Nature as a vehicle for self-praise and denigration of this country, this writer expects to be patted on the back by announcing his admiration for Oxford, Cambridge and Glasgow, and, perhaps, also expects to be invited to enjoy spells of "home weather".

Meanwhile, scientists and professors in India are supposedly employed in impeding not only the progress of science but also that of "conscientious" persons like your correspondent who "loves to teach but seeks to be evaluated on his research work".

Young engineering graduates, according to him, must not encroach upon physics, although an exception can be made in the case of Dirac because of his association with Cambridge.

The Indian science community is allegedly drawing inspiration from the members of one of the world's oldest professions. Will they be grateful for this dubious distinction conferred on them? They may have better decency and judgement.

The first impulse of many readers of Dwivedi's letter may be to condemn it to the oblivion it deserves, but the Indian Department of Science, the government, the national laboratories, institutes and universities and all Indians will have to take note of this denigration of India and Indian science in journals published abroad. Indian science and its administration are, unfortunately for Dwivedi, no longer the "white man's burden".

\section{s. S. Kushwaha}

Department of Physics,

Banaras Hindu University,

Varanasi 221005, India 